\title{
DEVELOPMENT OF AN AUTOMATED BATCH-PROCESS SOLAR WATER DISINFECTION SYSTEM
}

\author{
0. 0. Nwoke ${ }^{1,}{ }^{*}$, C. C. Mbajiorgu' ${ }^{2}$, I. P Owoh ${ }^{3}$ and E. C. Anoliefo ${ }^{4}$

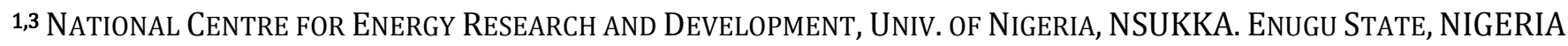 \\ 2 DePt. of Agricultural and Bioresources EngineERING, UniV. of NigERIA, NSUKKA., ENUGU STATE NIGERIA \\ 4DEPARTMENT OF ELECTRONIC ENGINEERING, UNIVERSITY OF NIGERIA, NSUKKA, ENUGU STATE NIGERIA

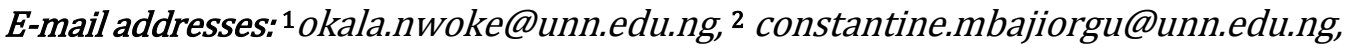 \\ 3ikechukwu.owoh@unn.edu.ng, 4 edward.anoliefo@unn.edu.ng
}

\begin{abstract}
One of the shortcomings of solar disinfection of water (SODIS) is the absence of a feedback mechanism indicating treatment completion. This work presents the development of an automated batch-process water disinfection system aimed at solving this challenge. Locally sourced materials in addition to an Arduinomicro processor were used to control the algorithm of the water disinfection system. A comparison of solar radiation sensing accuracy of the system to the Campbell Stokes instrument using student's $t$-test showed no significance difference between the two data sets at $p=0.05$. Test conducted with Escherichia Coli spiked water shows that a $6 \log$ reduction in CFU/ml was achieved within 15 minutes for an average global solar irradiance of $400 \mathrm{~W} / \mathrm{m}^{2}$. The system disinfected 11 litres of water in a day for solar radiation of $8.5 \mathrm{MJ} / \mathrm{m}^{2} /$ day and Escherichia coli concentration not exceeding $10^{6} \mathrm{CFU} / \mathrm{ml}$.
\end{abstract}

Keywords: water, disinfection, Escherichia Coli, solar, photo-catalysis.

\section{INTRODUCTION}

More than one billion people lack access to improved potable water, and an estimated three million people in developing countries die each year from infectious diseases related to unsafe water and inadequate sanitation [1]. Disinfection is the removal or destruction of all harmful microorganisms [1] and technically differs from sterilization which is the destruction or removal of all life forms. In rural Nigeria, many drink untreated water from natural water sources. The source of the water largely determines the physical, chemical and microbial qualities of the water. Water sources, in order of decreasing microbial quality include springs, boreholes, sealed wells, hand dug wells, roof harvested rainwater, streams, rivers and lakes [2]. Springs and boreholes tap ground water sources that have been filtered through layers of soil and rock and are isolated from the surface. These sources may contain unpleasant colour, odour and/or minerals, but are generally free from pathogenic contaminations and may not require disinfection. Sealed wells are shallow wells that have been sealed with cement around a pump to prevent contamination. However, contamination is possible. Wells become contaminated from improper usage and from contaminated water entering the well from above, particularly during flooding as was witnessed in some parts of Nigeria in the rainy months of 2012. Harvested rainwater, streams, rivers and lakes usually contain pathogens and require disinfection.

Consumption of bottled water and to a larger extent, polyethylene packaged sachet water is common in many places in Nigeria. Apart from the ecological problems posed by the discarded water bottles and sachets due to the near absence of sound environmental management practices in the form of recycling and waste management, some studies [3 - 6] in different parts of the country have revealed the dangerously poor microbiological quality of some polyethylene packaged water. It is therefore not surprising that water borne diseases are prevalent in Nigeria. Nwidu et al. [7] reported that in 2007, approximately $50 \%$ of all cases brought to a general hospital in the Niger Delta area of Nigeria were diagnosed of water borne diseases. The water related diseases that were consistently reported and diagnosed for the period are cholera (3.37\%), diarrhea (44.94\%), dysentery (16.85\%), and typhoid fever (34.83\%). The current situation in many rural areas may not be significantly different.

Several methods are in use for water disinfection. Some of the common methods include; the use of chemicals, 
filtration and water boiling [8]. These methods have their respective short comings ranging from formation of carcinogenic substances, clogging of filters to unavailability/high cost of fuels for boiling water.

Solar disinfection (SODIS) of water is a simple, environmentally sustainable, low-cost solution for drinking water treatment at house-hold level[9].The process usually involves filling transparent bottles with contaminated water and subsequently exposing the filled containers to sunlight for some period of time. Meierhofer et al. [9] recommends exposing the filled containers to full sunlight for six hours otherwise for two consecutive days if cloudiness exceeds $50 \%$ of the sunshine hours in the first day of exposure. It is also recommended that solar disinfected water should be consumed within $24 \mathrm{~h}$ to avoid the possibility of postexposure re-growth[10]. Pathogenic microorganisms are vulnerable to two effects of the radiation in the sunlight which are spectrum of UV-A light and heat[9]. Though the UV-A wavelengths bordering on visible light are not sufficiently energetic to directly modify DNA bases of pathogens, they play an important role in formation of reactive oxygen species (ROS) in water such as singlet oxygen, superoxide, hydrogen peroxide, and hydroxyl radical [10].

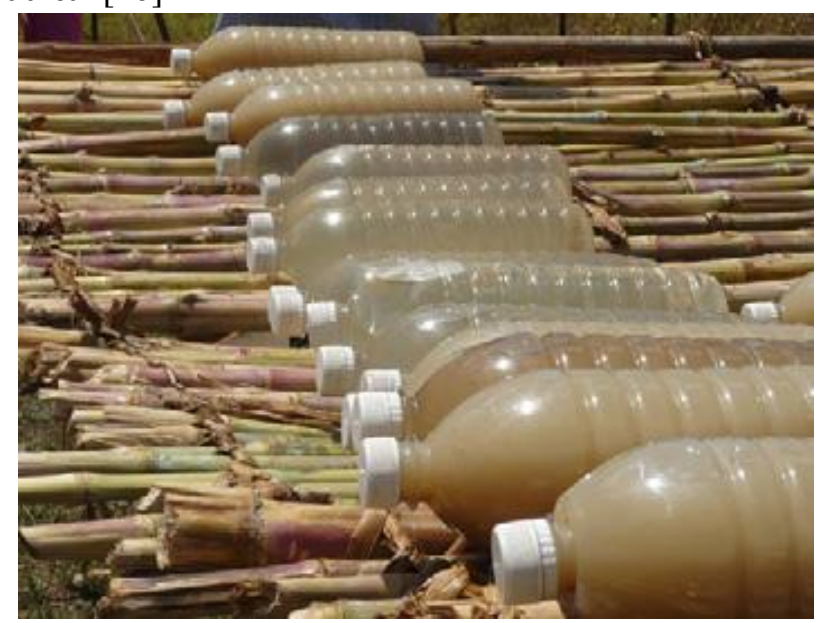

(a)

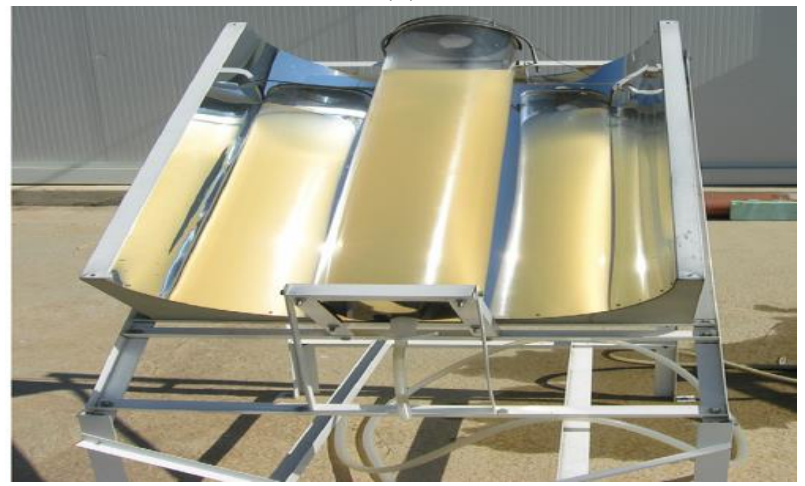

(b)

Fig. 1: (a) SODIS in traditional form, (b) SODIS enhanced batch reactor, (source: McGuigan et al. [10])
Once formed, these ROS can cause damage to DNA by the oxidations of amino acids in proteins and oxidations of poly-unsaturated fatty acids in lipids [10]. At a water temperature of $50^{\circ} \mathrm{C}$, only a fourth of the amount of UVlight required at $30^{\circ} \mathrm{C}$ is necessary to inactivate the same amount of faecal coliforms [9].

Water disinfection by sunlight could either be done in batch processes or continuous flow processes. A pictorial view of SODIS done with plastic containers is shown in Figure 1 (a) while SODIS done with an enhanced batch reactor is shown in Figure 1 (b).

One of the shortcomings of SODIS is the absence of a feedback mechanism indicating treatment completion. Polo-López et al. [11] in an attempt to solve this challenge developed an automatic batch SODIS process system, controlled by UVA-radiation sensors, which ensures that when the required UV-A dose to achieve complete disinfection is received, water is evacuated from the reactor and fresh water to be treated pumped into the reactor. This system reduces user work-load through automatic sequential batch processing but must be built based on the knowledge of the minimum lethal UV-A dose to be received. This dose depends on the concentration of the pathogen(s) and the geometry of the reactor[11]. The time to receive this dose will more or less be site/region specific given the spatial variation of solar radiation. The UVA dose can be calculated as follows[11];

$$
\text { Dose }\left(\mathrm{J} \mathrm{m} \mathrm{-2)}=\int U V A\left(W m^{-2}\right) d t(s) C\right.
$$

where UVA is the solar irradiance $(320-400 \mathrm{~nm})$ incident upon the reactor; $d t$ is the exposure time; and $C$ is the concentration factor of the mirror. $C$ is a dimensionless number that defines the multiplication factor by which sunlight is concentrated at the absorber/receiver. In this case, the absorber is the glass tube of the photo-reactor.

This work presents the development of a system that could be used to determine the lethal solar radiation dose for different reactor tube dimensions as well as different compound parabolic concentrator (CPC) regimes. Such a system could be used for pioneer studies in areas where solar water disinfection has not been studied and reported. It could also serve as a point-of-use water treatment system for homes. Unlike the work reported by Polo-López et al. [11], it uses commonly available rechargeable lantern photovoltaic cell as sensor for solar radiation. Other system components are also locally sourced.

\section{MATERIALS AND METHODS}

\subsection{Materials}

The materials used in developing the automated batchprocess solar water disinfection system include the 
following; (a) borosilicate glass tube measuring $64 \mathrm{~cm}$ in length with internal and external diameters of $40 \mathrm{~mm}$ and $36 \mathrm{~mm}$ respectively as reactor tube, (b) a borosilicate glass rod with a length of $60 \mathrm{~cm}$ and diameter of $6.9 \mathrm{~mm}$ as substrate for deposition of $\mathrm{TiO}_{2}$. The glass wares were custom shaped at Scientific Equipment Development Institute (SEDI) Enugu, (c) Two discarded but functional car wiper pumps for pumping into and out of the reactor tube, (d) Titanium dioxide (Degussa P-25) as a photo catalyst, (e) an Arduino® microprocessor for automated control of water into and out of the reactor, (e) water level sensors for sensing fullness and emptiness of the reactor, (f) a photovoltaic cell originally made for charging a hand held lantern for sensing solar radiation (g) temperature sensor for sensing temperature of the reactor, (h) an LCD display screen for displaying instantaneous solar irradiance $\left(\mathrm{W} / \mathrm{m}^{2}\right)$, accumulated radiation $\left(\mathrm{J} / \mathrm{m}^{2}\right)$, duration $(\mathrm{s})$ and reactor temperature $\left({ }^{\circ} \mathrm{C}\right)(\mathrm{i})$ a $2 \mathrm{~GB}$ memory card for data storage (j) a compound parabolic concentrator made of an aluminum reflector for concentration of radiation unto the reactor tube $(\mathrm{k})$ two water containers (one of the containers is for the contaminated water while the other is for the treated water), (l) signal and power cables (m) a 12 volts, 18 AH battery for powering the system and (n) two $10 \mathrm{~W}_{\mathrm{p}} \mathrm{PV}$ modules for charging the battery system. A schematic diagram of the setup is shown in Figure 2 while the pictorial view is shown in Figure 3.

\subsection{The water Disinfection System Set Up}

The reactor tube has a glass rod on which $\mathrm{TiO}_{2}$ has been deposited is held in place in its centre. The glass rod is held in postion with perforated rubber corks at the two ends of the tube. The reactor tube with the glass rod is positioned at the focus a CPC reflector. Water level sensors in the tube control the operations of the pumps. When the reactor tube is empty, the water level sensors send a signal to the Arduino® micro processor which in turn activates the inlet pump to pump untreated water into the reactor. When the reactor gets full, the inlet pump is deactivated. The outlet pump is activated when the reactor has received a given dose of solar radiation (Joules) preset at the beginning of the experiment/disinfection process.

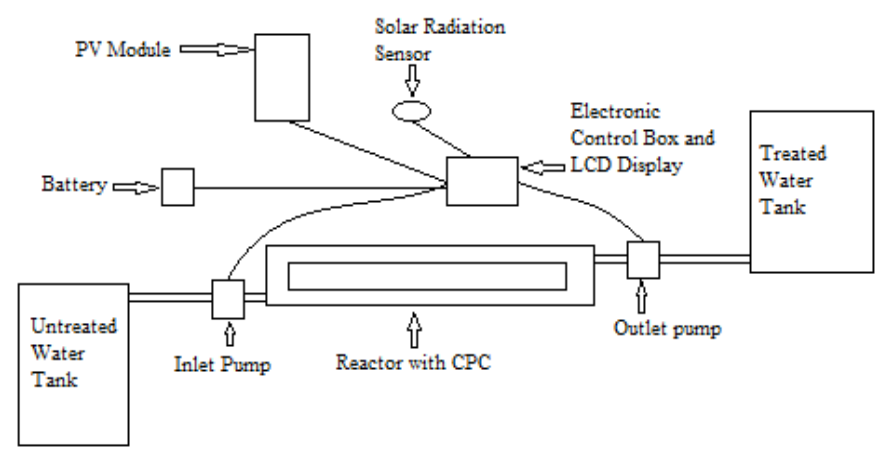

Fig. 2: Schematic diagram of the automated batchprocess solar water disinfection system

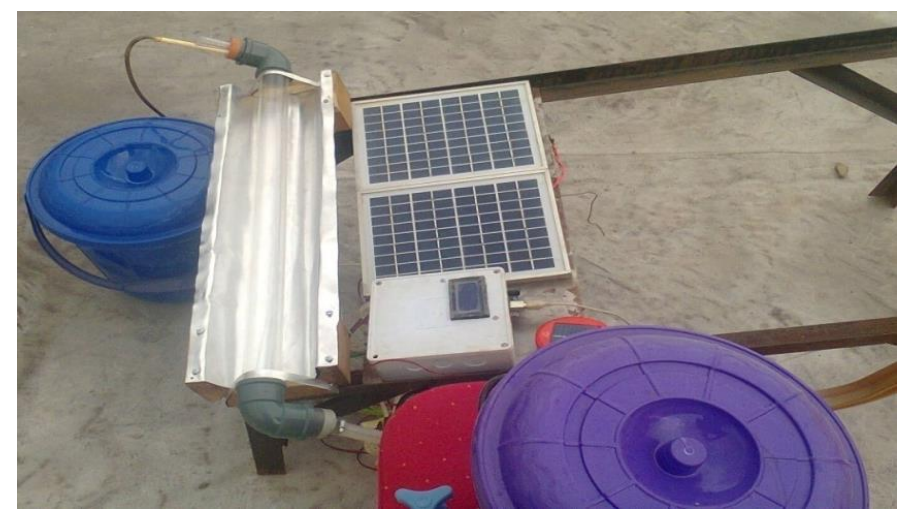

Fig. 3: Pictorial view of the automated batch-process solar water disinfection system

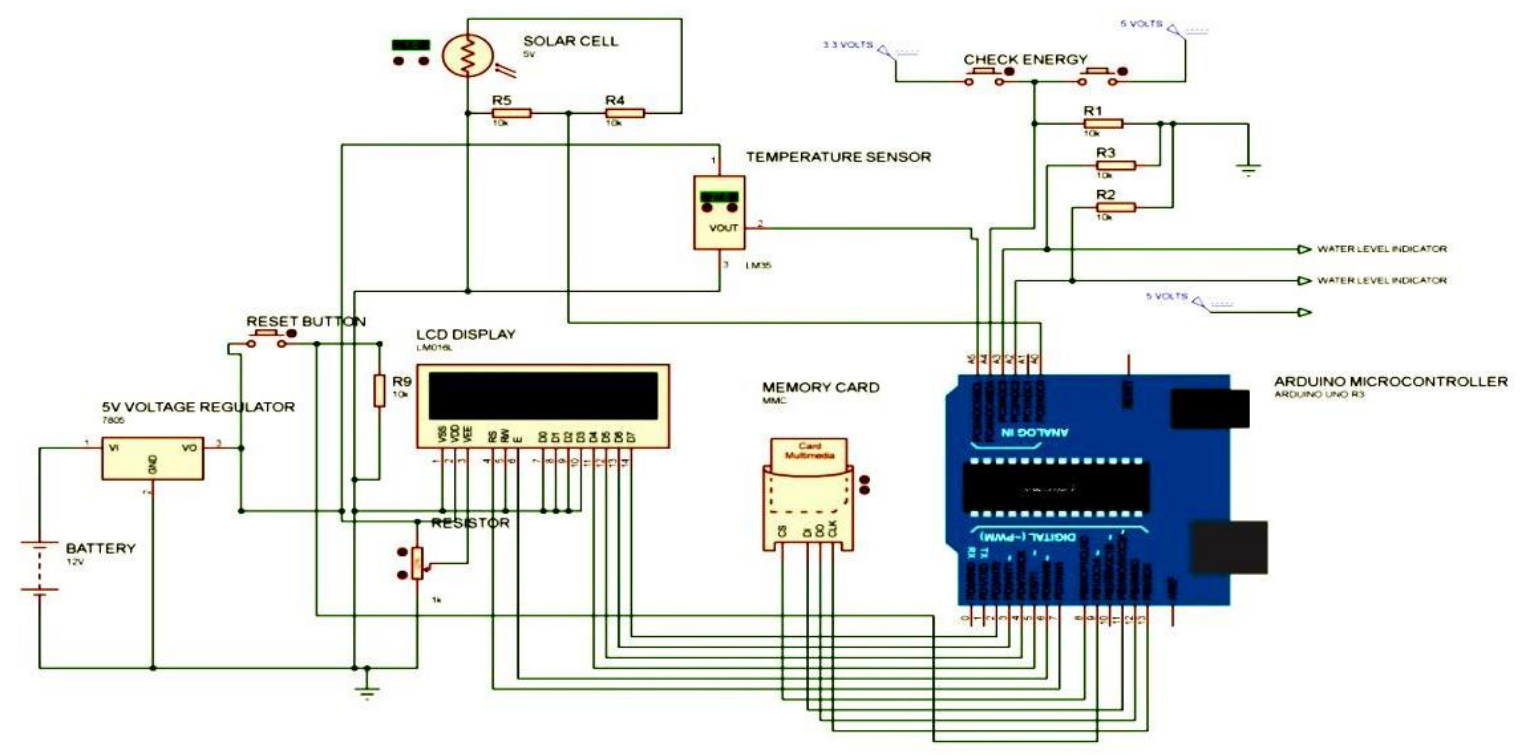

Figure 4: Circuitry of Arduino® microcontroller with the different sensors 
The solar radiation is sensed by a photovoltaic cell originally made for charging a hand held lantern and data logged with a memory card in the microprocessor. The circuit diagram showing the Arduino ${ }^{\circledR}$ microcontroller with the different sensors is shown in Figure 4.

\subsection{Solar Radiation Sensing}

The output voltage of a silicon based PV cell measuring 5 $\mathrm{cm}$ by $5 \mathrm{~cm}$ originally in use for a d.light rechargeable lantern with product number as S2 was used for solar irradiance sensing and solar radiation logging. The logic of the solar radiation sensing is set to calculate irradiation (I) in joules for a given time interval (dt) at which irradiance $(G)$ level measured in watts is the same for an area (A) and is given as;

$$
I(J)=\int G\left(J / m^{2}\right) A\left(m^{2}\right) d t
$$

while the required solar radiation dose $\left(S_{d}\right)$ measured in Joules which is also the preset radiaton dose is logged thus;

$$
S_{d}(J)=\sum_{t=0}^{t=\text { dose time }} I(J)
$$

\subsection{Water Level Sensing}

Water level sensing was implemented with the use of three copper wires. One of the wires serves as a voltage source while the other wire probes serve as full and empty reactor sensors. The logic is based on the conductivity of water. As shown in Figure5, the input pump keeps pumping until the copper probe in use as sensor for full reactor senses the voltage signal from the signal source.

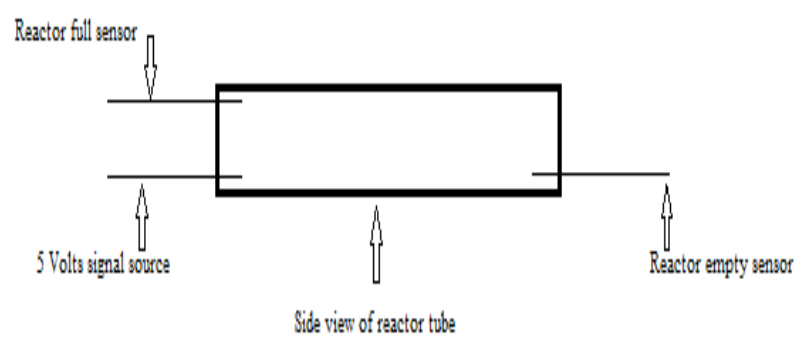

Fig. 5: Schematics of the water sensors

This happens when the water in the reactor touches the 'Reactor full sensor'. At this point, the input pump is deactivated and solar radiation sensor initiates the recording of the preset radiation dose. Once the dose has been achieved, the output pump starts pumping and only stops pumping when the voltage signal cannot be seen by the 'Reactor empty sensor'. At this point, the output pump is deactivated and a delay of 30 seconds is

observed before the input pump is activated. This cycle goes on and on.

\subsection{Immobilization of $\mathrm{TiO}_{2}$ Unto the Glass Rod}

The glass rod was washed with a $5 \%$ detergent solution and rinsed with tap water until the foam on the rod could no longer be noticed. The washing and rinsing was repeated three times after which the rod was thoroughly rinsed with distilled water. The glass rod was then sonicated in a distilled water bath for 15 mins. This sonication process was repeated three times. After the sonication, the rod was dried in the oven at $105^{\circ} \mathrm{C}$ for $1 \mathrm{~h}$ before being weighed. A $1 \%$ solution of Degussa P-25 $\mathrm{TiO}_{2}$ was prepared with distilled water and sonicated for 15 min. The rod was swirled in the $\mathrm{TiO}_{2}$ solution until coated. The rod was then placed into an oven for $10 \mathrm{~min}$ until the layer dried. This step was repeated 15 times to ensure adequate coating. The rod was then annealed at $300{ }^{\circ} \mathrm{C}$ for $10 \mathrm{hrs}$. The initial weight of the rod was $51.701 \mathrm{~g}$ while the weight of the rod after $\mathrm{TiO}_{2}$ deposition and annealing was $51.744 \mathrm{~g}$. Given the effective volume of the reactor as 0.6 litres, the concentration of the $\mathrm{TiO}_{2}$ becomes $86 \mathrm{mg} / \mathrm{litre}$.

\subsection{Bacterial Preparation And Enumeration}

Escherichia coli K-12 (ATCC 10798) was used as the model bacterium in this study due to its widespread use as a faecal indicator. A single colony was inoculated in 50 $\mathrm{ml}$ of sterile Luria broth (Sigma L3522) and incubated statically at $37{ }^{\circ} \mathrm{C}$ for $18 \mathrm{~h}$ to yield stationary phase culture. The culture was then washed by centrifugation three times at $3000 \mathrm{rpm}$ for $15 \mathrm{~min}$ to ensure the elimination of the broth medium. Finally, the pellet was resuspended and diluted to a final concentration of $1 \mathrm{x}$ $10^{9} \mathrm{CFU} / \mathrm{ml}$ in sterile water. One millilitre of bacteria was then added to each litre of water used in the experiment to give an initial concentration of $1 \times 10^{6} \mathrm{CFU} / \mathrm{ml}$. The number of viable cells in the water samples taken during the experiment were determined by plating an appropriate dilution on Luria Agar (Sigma L3147) and counting colonies after incubation at $37^{\circ} \mathrm{C}$ for $18 \mathrm{~h}$.

\subsection{System Evaluation}

\subsubsection{Recorded Solar Radiation Test}

The first test was done to check that the whole system was working as designed and planned.This was carried out in the vicinity of the weather station at the Centre for Basic Space Science, Nsukka. The water disinfection system was set up and tested with ordinary tap water. The system was set to operate at the following solar radiation doses; $50 \mathrm{KJ} / \mathrm{m}^{2}, 100 \mathrm{KJ} / \mathrm{m}^{2}, 150 \mathrm{KJ} / \mathrm{m}^{2}, 300$ $\mathrm{KJ} / \mathrm{m}^{2}$ and $500 \mathrm{KJ} / \mathrm{m}^{2}$. Solar radiation data from the weather station was used to assess the data logging 
ability of the developed system. This was done by comparing the global solar radiation measured by the Campbell Stokes $\mathbb{B}$ Instrument at the weather station to the preset radiation dose of the water disfection system for a partcular test. The two sets of data were then analysed statistically using student's $t$ - test. This experiment was conducted on the $1^{\text {st }}$ of December, 2015.

\subsubsection{Water Disinfection Test}

The test was conducted at the National Centre for Energy Research and Development, University of Nigeria, Nsukka on the $21^{\text {st }}$ of March, 2016.A water volume measuring 25 litres was spiked with E. Coli and introduced into the untreated water tank of the water disinfection system. The untreated water tank was covered with aluminum foil to avoid the penetration of sunlight. Some of the spiked water (0.5 litres) was also put in a reactor tube of same dimension as the reactor tube of the disinfection system but covered with the alumnium foil and left in the dark to serve as control. Initial samples were collected from the untreated water tank and the dark control respectively with $10 \mathrm{ml}$ syringes. All samples were kept in the test tubes and left in the dark to avoid exposure to solar radiation. The first test was set such that the outlet pump is activated when the reactor tube has received $100 \mathrm{KJ} / \mathrm{m}^{2}$ of global solar radiation. The tests were subsequently carried out for $200 \mathrm{KJ} / \mathrm{m}^{2}, 300 \mathrm{KJ} / \mathrm{m}^{2}$ and $400 \mathrm{KJ} / \mathrm{m}^{2}$ of solar radiation. Samples for analysis were collected every two minutes.

\section{RESULTS AND DISCUSSION}

\subsection{Results}

\subsubsection{Recorded Solar Radiation Test Result}

The two sets of solar radiation data; i.e. the preset solar radiation doses on the water disinfection system and the other from theCampbell Stokes@for the same time periods are shown in Table 1. A statistical analysis using $\mathrm{t}$ test showed no significant difference at $p=0.05$ for the data sets. It could therefore be concluded that data from the improvised solar sensor and data logger are as good as the data from the weather station.

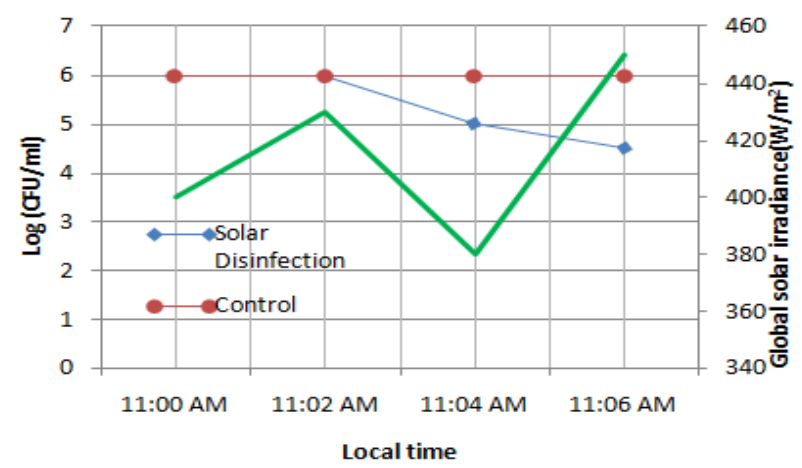

Fig 6: Water disinfection results for a $100 \mathrm{KJ} / \mathrm{m}^{2}$ dose solar radiation
Table 1: Comparism of preset dose to estimated dose from weather station.

\begin{tabular}{llllll}
\hline Preset doses $\left(\mathrm{KJ} / \mathrm{m}^{2}\right)$ & 50 & 100 & 150 & 300 & 500 \\
\hline Calculated doses $\left(\mathrm{KJ} / \mathrm{m}^{2}\right)$ & 52 & 98 & 147 & 302 & 499 \\
\hline
\end{tabular}

\subsubsection{Water disinfection test result}

The water disinfection results obtained with the water disinfection system preset to receive $100 \mathrm{KJ} / \mathrm{m}^{2}, 200$ $\mathrm{KJ} / \mathrm{m}^{2}, 300 \mathrm{KJ} / \mathrm{m}^{2}$ and $400 \mathrm{KJ} / \mathrm{m}^{2}$ are presented in Figures6, 7, 8 and 9.

\subsection{Discussion}

As already mentioned in section 3.1.1, a statistical analysis using $\mathrm{t}$ test showed no significant difference at $p=0.05$ for the data sets from the water disinfection system and the Campbell Stokes Instrument at Space Centre's weather station. It could therefore be concluded that data from the improvised solar sensor and data logger are as good as the data from the weather station.

From fig. 3.3, exposure of the spiked water to a preset solar dose of $300 \mathrm{KJ} / \mathrm{m}^{2}$ was able to have a $6 \mathrm{log}$ reduction in the concentration of the indicator organism. Given the solar radiation regime at the time of the experiment, $8 \mathrm{~min}$ was used to achieve this $6 \mathrm{log}$ reduction. Exposure to a preset dose of $400 \mathrm{KJ} / \mathrm{m}^{2}$ also achieved the $6 \log$ reduction. It therefore follows that $300 \mathrm{KJ} / \mathrm{m}^{2}$ is the minimum solar radiation dose amongst the doses tested for the complete elimination of the indicator organism. Preset values of $100 \mathrm{KJ} / \mathrm{m}^{2}$ and 200 $\mathrm{KJ} / \mathrm{m}^{2}$ could only achieve $1.5 \log$ reductions. It could also be noticed that the control samples maintained the original concentration of $10^{6} \mathrm{CFU} / \mathrm{ml}$ of E.Coli which buttresses the efficacy of the solar water disinfection system. It could therefore be concluded that a water disinfection system utilizing immobilized $\mathrm{TiO}_{2}$ and of a similar geometry to the one used in this test will require a minimum dose of $300 \mathrm{KJ} / \mathrm{m}^{2}$ solar radiation to achieve a $6 \log$ reduction of $E$. coli $K-12$ (ATCC 10798).

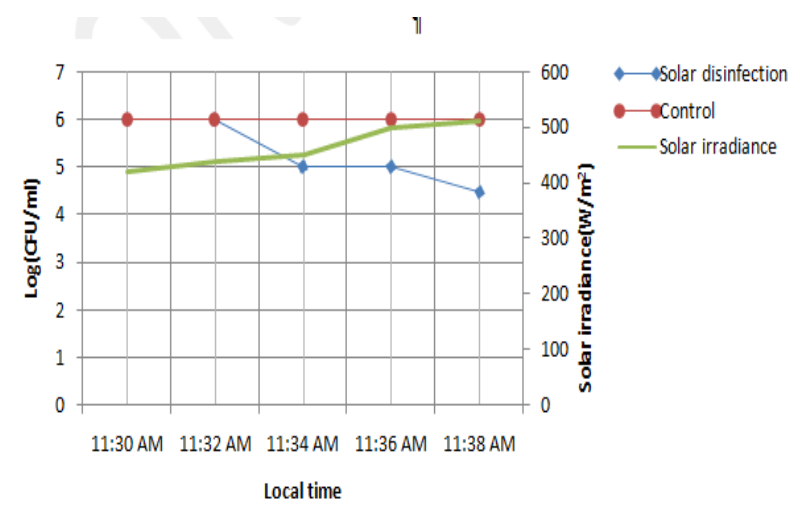

Fig 7: Water disinfection results for a $200 \mathrm{KJ} / \mathrm{m}^{2}$ dose solar radiation 


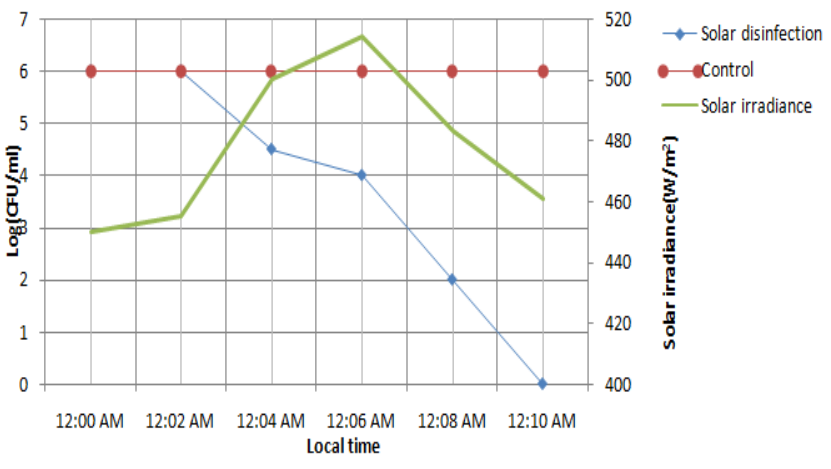

Fig. 8: Water disinfection results for a $300 \mathrm{KJ} / \mathrm{m}^{2}$ dose solar radiation

It would be necessary to carry out this test at other times in the year given that the portion of UV radiation reaching the site of interest could be functions of seasonal cloud covers.

\section{CONCLUSION}

An automated water disinfection system built on the principles of solar photo catalysis was developed with locally sourced materials. The system could be used to determine the minimum solar dose required to disinfect water of known microbial contaminants' type and concentration for a given system geometry under study. Once this lethal dose has been established, the system studied could be deployed as a point-of-use water disinfection system for homes and communities. The automated system could also be used to study the minimum time required for solar water disinfection (SODIS) without the use of a photocatalyst. Results from such studies could be beneficial in developing localized guidelines with respect to exposure times required for SODIS.

The minimum solar dose to achieve a 6 log reduction in $\mathrm{CFU} / \mathrm{ml}$ of E. coli in Nsukka and around March is 300 $\mathrm{KJ} / \mathrm{m}^{2}$ for a solar photocatalytic reactor with the same dimensions as the one used in this study. On a relatively clear day in March, this global solar radiation dose could be recorded in a period not longer than 15 mins. However, exposure to a longer duration hence higher solar dose could add a greater margin of safety with respect to water disinfection. The system could disinfect up to 11 litres of water per day given that solar radiation is up to $8.5 \mathrm{MJ} / \mathrm{m}^{2} /$ day and Escherichia Coli concentration does not exceed $10^{6} \mathrm{CFU} / \mathrm{ml}$.

\section{REFERENCES}

[1] H. D. Backer, The Travel and Tropical Medicine Manual:Chapter 8 - Water Disinfection, 4th editio. Elsevier, 2008.

[2] J. D. Burch and K. E. Thomas, "Water disinfection for developing countries and potential for solar thermal

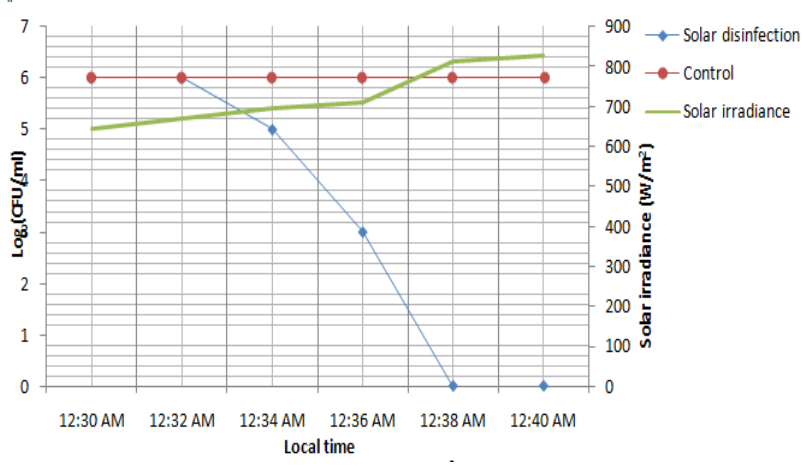

Fig. 9: Water disinfection results for a $400 \mathrm{KJ} / \mathrm{m}^{2}$ dose solar radiation

pasteurization," Sol. Energy, vol. 64, no. 98, pp. 87-97, 1998.

[3] O. A. Adegoke, E. O. Bamigbowu, E. S. Oni, and K. N. Ugbaja, "Microbiological examination of sachet water sold in Aba, Abia State, Nigeria.," Glob. Res. J. Microbiol., vol. 2, no. 1, pp. 62-66, 2012.

[4] O. Oyedeji, P. O. Olutiola, and M. A. Moninuola, "Microbiological quality of packaged drinking water brands marketed in Ibadan metropolis and Ile-Ife city in South Western Nigeria," African J. Microbiol. Res., vol. 4, pp. 96-102, 2010.

[5] J. C. Onweluzo and C. A. Akuagbazie, "Assessment of the quality of bottled and sachet water sold in Nsukka town," Agro Sci. J. Trop. Agric. Food, Environ. Ext., vol. 9, no. 2, pp. 104-110, 2010.

[6] 0. A. Olaoye and A. A. Onilude, "Assessment of microbiological quality of sachet-packaged drinking water in Western Nigeria and its public health significance," Public Health, vol. 123, no. 11, pp. 729734, 2009.

[7] L. L. Nwidu, B. Oveh, T. Okoriye, and N. A. Vaikosen, "Assesment of the water quality and prevalence of water borne diseases in Amassoma, Niger Delta, Nigeria," African J. Biotechnol., vol. 7, pp. 2993-2997, 2008.

[8] A. 0. Sojobi, S. I. Dahunsi, and A. O. Afolayan, "Assessment of the Efficiency of Disinfection Methods Method S for Improving Water Quality," Niger. J. Technol., vol. 34, no. 4, pp. 907-915, 2015.

[9] M. H. Regula Meierhofer and Martin Wegelin, Xiomara del Rosario Torres, Bruno Gremion, Alvaro Mercado, Daniel Mäusezahl and B. G. and C. A. Stephan Indergand-Echeverria, Solar Water Disinfection: $A$ guide to the application of SODIS. 2002.

[10] K. G. McGuigan, R. M. Conroy, H.-J. Mosler, M. du Preez, E. Ubomba-Jaswa, and P. Fernandez-Ibañez, "Solar water disinfection (SODIS): a review from bench-top to roof-top.," J. Hazard. Mater., vol. 235-236, pp. 2946, Oct. 2012.

[11] M. I. Polo-López, P. Fernández-Ibáñez, E. UbombaJaswa, C. Navntoft, I. García-Fernández, P. S. M. Dunlop, M. Schmid, J. a Byrne, and K. G. McGuigan, "Elimination of water pathogens with solar radiation using an automated sequential batch CPC reactor.," J. Hazard. Mater., vol. 196, pp. 16-21, Nov. 2011. 